\title{
THE POTENTIAL CARDIOPROTECTIVE EFFECT OF MATRICARIA CHAMOMILLA EXTRACT AGAINST DIABETES-INDUCED OXIDATIVE STRESS IN RATS
}

\author{
GAMAL A. SOLIMAN ${ }^{1,2}$, SHERIF A. ABDEL-GAWAD ${ }^{3,4}$, MOHD N. ANSARI $^{1 *}$, ABDUL-MALEK \\ S. ALTAMIMI ${ }^{3}$, HOSSNY A. EL-BANNA ${ }^{2}$, HISHAM Y. ELZORBA ${ }^{2}$, NOHA F. HASSAN ${ }^{5}$ \\ ${ }^{I}$ Department of Pharmacology, College of Pharmacy, Prince Sattam bin Abdulaziz University, Al-Kharj, Kingdom of Saudi Arabia \\ ${ }^{2}$ Department of Pharmacology, College of Veterinary Medicine, Cairo University, Egypt \\ ${ }^{3}$ Department of Pharmaceutical Chemistry, College of Pharmacy, Prince Sattam bin Abdulaziz University, Al-Kharj, \\ Kingdom of Saudi Arabia \\ ${ }^{4}$ Department of Analytical Chemistry, College of Pharmacy, Cairo University, Egypt \\ ${ }^{5}$ Global Pharma Factory, Cairo, Egypt
}

*corresponding author: nazam.ansari@gmail.com

Manuscript received: February 2019

\begin{abstract}
Diabetes mellitus (DM) has been associated with several complications, such as cardiac dysfunction. The aim of the present study was to explore the effect of the Matricaria chamomilla flower extract (MCE) against the harmful effect of DM on the cardiac muscles of rats. DM was induced in overnight fasted rats through a single injection of streptozotocin (STZ, $45 \mathrm{mg} / \mathrm{kg}$ b.w., i.p.). The thirty-six rats were divided into six equal groups. Non-diabetic rats of the first and second groups were treated with vehicle ( $2 \mathrm{~mL} / \mathrm{kg} \mathrm{b.w.)}$ and MCE (400 mg/kg b.w.), respectively. The third to sixth groups were diabetic rats that received vehicle, glibenclamide (GLB, $5 \mathrm{mg} / \mathrm{kg}$ b.w.), and a low and high dose of MCE, respectively, for 10 weeks. Fasting blood glucose (FBG) and insulin levels were estimated at 0 and 10 weeks. In addition, cardiac damage was assessed by estimating the lipid profile, AST, LDH, CK, CK-MB and cardiac troponin (cTnI) levels in the serum, cardiac and left ventricle hypertrophy indices, and cardiac oxidative stress biomarkers, followed by histopathological studies. GLB and MCE significantly reduced the FBG levels, in comparison with the STZ control rats. The beneficial impacts of MCE at $400 \mathrm{mg} / \mathrm{kg}$ were better than GLB in improving the levels of cardiac damage and lipid profile biomarkers of STZ-diabetic rats. Following the MCE medication, the haemodynamic parameters and histopathological alterations in the cardiac tissues of rats improved. In conclusion, MCE exhibited a marked protective activity against diabetes-induced cardiac dysfunction in rats.
\end{abstract}

\section{Rezumat}

Diabetul zaharat (DM) a fost asociat cu multe comorbidități, cum ar fi disfuncția cardiacă. Scopul prezentului studiu a fost de a explora efectul extractului de flori de mușețel (MCE) asupra funcției cardiace a șobolanilor cu DM indus experimental printr-o singură doză de streptozotocină (STZ, $45 \mathrm{mg} / \mathrm{kg}$ corp, i.p.). Cei treizeci și șase de șobolani au fost împărțiţi în șase grupuri. Șobolanii non-diabetici din primul și al doilea grup au fost tratați cu 3\% Tween $80(2 \mathrm{~mL} / \mathrm{kg}$ corp) și, respectiv, MCE (400 mg/kg corp). Al treilea până la al șaselea grup au fost șobolani diabetici care au primit Tween, glibenclamidă (GLB, 5 mg/kg corp) și diferite doze de MCE, timp de 10 săptămâni. Nivelul glucozei din sânge (FBG) și al insulinei au fost estimate la 0 și 10 săptămâni. În plus, afectarea cardiacă a fost evaluată prin estimarea profilului lipidic, AST, LDH, CK, CKMB și troponină serică (cTnI), a indicilor de hipertrofie cardiacă, biomarkeri de stres oxidativ cardiac, precum şi studii histopatologice. GLB și MCE au redus semnificativ nivelul FBG, în comparație cu șobolanii control STZ. Efectul benefic al MCE în doză de $400 \mathrm{mg} / \mathrm{kg}$ a fost superior comparativ cu GLB în ceea ce privește îmbunătăţirea profilului lipidic și a biomarkerilor miocardici. De asemenea, s-au normalizat parametrii hemodinamici și s-au ameliorat modificările histopatologice. În concluzie, MCE a relevat efect protector asupra disfuncției cardiace induse de diabet la șobolani.

Keywords: Matricaria chamomilla, STZ, diabetes, troponin, antioxidant, lipid peroxidation

\section{Introduction}

Diabetes mellitus (DM) is a group of metabolic disorders, also identified as hyperglycaemia. The most prevalent form of DM is type 2 diabetes (T2DM). A close link exists between DM and cardiovascular disorders, which is the most widespread cause of morbidity and mortality in diabetic patients [1]. Oxidative stress, accompanied by hyperglycaemia, plays a key role in the development of DM and its complications [2]. Thus, the aim of diabetes handling should be the reduction of blood glucose and oxidative stress to decline the danger of complications. Oral antidiabetic drugs are usually used for T2DM. GLB is one of the most common antidiabetic drugs belonging to sulfonylurea class. Even though diverse classes of antidiabetic drugs are obtainable for the long-term control of diabetes, and 
the consequent improvement of cardiac disorder, in part, the amelioration is only minor.

Herbaceous compounds are acquiring publicity in the management of DM and its complications. The pharmacological characteristics of herbaceous compounds, including the improvement of insulin sensitivity, assistance with insulin release, the augmentation of glucose uptake by fat and muscular tissues and the suppression of glucose absorption in the small intestine, have been demonstrated in several studies [3]. The Compositae family includes some beneficial medicinal genera such as Matricaria, Achillea, Artemisia, Taraxacum and Tussilago. Matricaria chamomilla L. is known by a variety of names, including Baboonig, Babunj, Babuna chamomile, German chamomile and English chamomile, due to its widespread use [4]. It demonstrated a marked antidiabetic activity, preserved the activity of pancreatic $\beta$-cells and reduced the hyperglycaemia-related oxidative stress [5]. Additionally, it is also used as a sedative as well as an anxiolytic, antispasmodic and an anti-inflammatory agent [4]. Some active constituents described in chamomile are triterpenic saponosides, terpenoids and alantolactones. The therapeutic effects of $M$. chamomilla $\mathrm{L}$ are mostly due to its phenolic constituents [6]. Although considerable attempts have been made for optimizing blood glucose levels, the diabetic complication remains the major cause of organ dysfunction. Our investigation aimed to assess the potential protective effects of MCE against the deleterious effect of DM on rat hearts.

\section{Materials and Methods}

\section{Preparation of $M$. chamomilla extract (MCE)}

The chamomile flower was procured from a local market in Al-Kharj city (KSA) in May 2018, and it was authenticated by the Laboratories of the College of Pharmacy of Prince Sattam bin Abdulaziz University. Dried chamomile flowers were weighed and crushed using an electric mill. The chamomile flower powder was extracted using a Soxhlet apparatus, in $1 \mathrm{~L}$ of ethanol $(70 \%)$. The pooled extract was filtered after 48 hours. The filtrate was concentrated using a rotary vacuum evaporator under reduced pressure until dryness. The extract was stored at $4^{\circ} \mathrm{C}$ and reconstructed with $3 \%$ Tween 80 to obtain different doses, when required to treat the animals.

\section{Animals}

Adult male Wistar rats weighing 200 - $225 \mathrm{~g}$ were obtained from the animal care unit of the College of Pharmacy, Prince Sattam bin Abdulaziz University, Al-Kharj, Kingdom of Saudi Arabia. The animals were provided with food and water ad libitum and kept at $21 \pm 2^{\circ} \mathrm{C}$ on a $12 \mathrm{~h}$ light-dark cycle. The study protocol was approved by the local Ethics Committee. Acute toxicity study

The acute toxicity of MCE was studied following the guidelines of the Organization for Economic Co- operation and Development [7]. The rats were kept on fasting overnight, being provided with only water prior to oral administration of MCE at different dose levels $(0.1,1.0,2.0$ and $4.0 \mathrm{~g} / \mathrm{kg}$ b.w.). The rats were allowed food and water ad libitum and were kept under observation for symptoms of toxicity and/or mortalities during the first $0.5 \mathrm{~h}$ and periodically for $24 \mathrm{~h}$, then daily for a total of 14 days.

Induction of DM

Experimental diabetes was induced in overnight fasted rats using an intraperitoneal injection of STZ (SigmaAldrich Corp, St. Louis, MO, USA) at a dose of 45 $\mathrm{mg} / \mathrm{kg}$ b.w., dissolved in $0.1 \mathrm{M}$ citrate buffer, $\mathrm{pH} 4.5$. For vehicle control rats, only the citrate buffer was administered. Three days later, diabetes was confirmed through the determination of FBG levels in the blood samples collected from the tail vein, using a blood glucose meter (Accu-Check Performa, Roche Diagnostic, Germany). Only rats with blood glucose levels > 250 $\mathrm{mg} / \mathrm{dL}$ were considered diabetic and included in the study.

\section{Experimental design}

The rats were randomly assigned into six groups, with each group consisting of six rats: 1 . Normal control group (NC): Non-diabetic rats treated with vehicle (3\% Tween 80, 2 mL/kg b.w.); 2. MCE-400 group: Non-diabetic rats treated with MCE $(400 \mathrm{mg} / \mathrm{kg}$ b.w.); 3. STZ control group: Diabetic rats treated with vehicle (3\% Tween $80,2 \mathrm{~mL} / \mathrm{kg}$ b.w.); 4. STZ plus GLB group: Diabetic rats treated with glibenclamide (5 mg/kg b.w.); 5. STZ plus MCE-200 group: Diabetic rats treated with MCE (200 mg/kg b.w.); 6. STZ plus MCE-400 group: Diabetic rats treated with MCE (400 mg/kg b.w.).

Three days after the STZ injection, GLB and the tested extract were suspended in 3\% Tween 80 and administered orally, once daily, using gastric gavage for 10 weeks. Tail-cuff blood pressure measurements

One day prior to euthanasia, systolic blood pressure (SBP), diastolic blood pressure (DBP) and heart rates (HR) were assessed in conscious animals by the tailcuff method, using a non-invasive blood pressure recorder (Ugo Basile SRL, Gemonio (VA) Italy). The procedure was performed after pre-warming the rats on a platform kept at $37^{\circ} \mathrm{C}$ for $10 \mathrm{~min}$. This allowed the rats to de-stress. The result represents the mean of five measurements; the rats were habituated to the procedure before registering the blood pressure.

Serum preparation

After recording the blood pressure and heart rate, blood samples were withdrawn through the retro-orbital venous plexus, under mild ketamine anaesthesia from the overnight fasted animals into sampling tubes. The blood samples were collected in dry tubes and left to rest for $30 \mathrm{~min}$ at room temperature. The serum was obtained through centrifugation (3000 $\mathrm{g}$ for $30 \mathrm{~min}$ ) and stored at $-20^{\circ} \mathrm{C}$. 
Estimation of cardiac and left ventricular hypertrophy indices

After collecting the blood, the animals were weighed and killed by decapitation. Subsequently, the hearts were excised, cleaned with phosphate buffer saline (PBS) and weighed. The left ventricles were separated and weighed and the cardiac and left ventricular hypertrophy indices were calculated as heart weight/body weight (HW/BW) and left ventricular weight/body weight (LVW/BW), respectively. The indices were adopted to prevent variations among different animal sizes.

Samples of the left ventricle were immediately frozen and stored at $-70^{\circ} \mathrm{C}$ for biochemical analyses, and the remaining portions were fixed in $10 \%$ buffered formalin for histopathological studies.

\section{Estimation of serum glucose and insulin levels}

The FBG levels in the serum were measured at the beginning of the experiment (0-time) and at the end of the $10^{\text {th }}$ week of treatments using commercially available kits (Spinreact, Spain), while the serum insulin levels were determined using Enzyme Linked Immunosorbent assay (ELISA) kits (Cobas, Belgium), following the manufacturer's instructions.

Estimation of serum myocardial injury markers

Serum levels of aspartate transaminase (AST), lactate dehydrogenase $(\mathrm{LDH})$, creatine kinase $(\mathrm{CK})$ and creatine kinase-muscle/brain (CK-MB) were estimated using standard respective kits (Sigma-Aldrich, USA) and an UV spectrophotometer (Model-150-200, Hitachi, Japan); all instructions of the manufacturer were followed. Serum cTnI was measured using rat-specific cTnI kits (Life Diagnostics Inc, West Chester, USA). Estimation of serum lipids and lipoproteins

Serum levels of triglycerides (TGs), total cholesterol (TC), high-density lipoprotein cholesterol (HDL-C) and low-density lipoprotein cholesterol (LDL-C) were estimated, according to the instructions manual of commercially available enzymatic kits.

Very-low-density lipoprotein cholesterol (VLDL-C) and the atherogenic index (AI) were calculated using the following formula [8]:

$$
\begin{gathered}
\text { VLDL-C = TGs/5, } \\
\mathrm{AI}=(\mathrm{TC}-\mathrm{HDL}) / \mathrm{HDL} .
\end{gathered}
$$

Estimation of oxidant and antioxidant biomarkers in the heart tissue

The left ventricle samples were homogenized in a chilled Tris - $\mathrm{HCl}$ buffer $(0.1 \mathrm{M})$ at $7.4 \mathrm{pH}$. The homogenate was then centrifuged at $10,000 \mathrm{rpm}$ at $4^{\circ} \mathrm{C}$, using the Hettich Universal Refrigeration Centrifuge Model. The obtained clear supernatant was used for the assay of superoxide dismutase (SOD), glutathione peroxidase (GPx), catalase (CAT) and reduced glutathione (GSH), spectrophotometrically, according to the commercial instructions of the kits. Lipid peroxidation products were estimated by determining malondi- aldehyde (MDA) content in the heart tissues, according to the procedure outlined by Jain et al. [9].

Histopathological examination

Heart tissues from each group were harvested and fixed in $10 \%$ neutral buffered formalin and routinely processed for paraffin embedding to obtain $4 \mu \mathrm{m}$ sections. The fixed tissues were embedded in paraffin, and then serial sections of $5 \mu \mathrm{m}$ thickness were cut. The sections of the hearts were stained with haematoxylin and eosin (H\&E) and evaluated for pathological changes of cardiotoxicity.

Statistical analysis

To explain the in vivo effects between the groups of animals, a one-way analysis of variance (ANOVA) was carried out by a computer software, Graph Pad Prism 5.01. The level of significance $(p<0.05)$ among the various treatments was determined through Dunnett's multiple comparison test.

\section{Results and Discussion}

Acute toxicity study

The acute toxicity study disclosed the nontoxic nature of the plant. The $\mathrm{LD}_{50}$ value of MCE through the oral route could not be determined, as no lethality was observed up to $4000 \mathrm{mg} / \mathrm{kg}$ b.w. in the rats.

\section{Effects of MCE in non-diabetic rats}

Non-diabetic rats that received MCE-400 for 10 weeks demonstrated non-significant $(\mathrm{p} \leq 0.05)$ alterations in FBG and serum insulin levels, in comparison with the NC animals. No statistically significant differences were noted in the serum levels of cardiac injury markers (AST, LDH, CK, CK-MB and cTnI) between non-diabetic rats treated with MCE-400 and the NC animals. The extract did not influence the cardiac hypertrophy index, SBP, DBP and HR in the nondiabetic rats. When compared to the NC group, animals that received MCE-400 for 10 weeks showed nonsignificant $(\mathrm{p} \leq 0.05)$ changes in their serum lipid profile and the levels of MDA in their cardiac tissues. The antioxidant enzymes and GSH in the myocardial tissues of non-diabetic animals increased following MCE treatment for 10 weeks.

Effects of MCE in diabetic rats

Effect on blood glucose and insulin levels

Table I shows the effect of GLB and MCE on FBG and insulin levels of rats, at the end of the $10^{\text {th }}$ week of medication. NC and STZ control animals did not demonstrate significant differences in FBG and insulin levels, as compared to their baseline values. A diabetogenic response, with marked elevation $(\mathrm{p} \leq 0.05)$ in the level of blood sugar levels $(272.8 \pm 8.16 \mathrm{mg} / \mathrm{dL})$ and a significant decrease $(p \leq 0.05)$ in the level of serum insulin $(3.1 \pm 0.18 \mathrm{U} / \mathrm{L})$ were observed in STZ control rats, rather than in the $\mathrm{NC}$ group $(79.8 \pm 4.92 \mathrm{mg} / \mathrm{dL}$ and $7.8 \pm 0.46 \mathrm{U} / \mathrm{L}$, respectively). However, the GLB and MCE-treated diabetic rats showed a significant $(p \leq 0.05)$ improvement in FBG and insulin levels, 
FARMACIA, 2020, Vol. 68, 2

when compared to the STZ control group. The antihyperglycaemic activity of GLB (64.07\%) was superior to that of MCE-200 (45.21\%) and MCE-400 (49.89\%), in comparison to their day- 0 values.

Table I

Effect of GLB and MCE on the FBG and insulin levels of STZ-diabetic rats

\begin{tabular}{|l|c|c|c|c|c|c|}
\hline \multirow{3}{*}{ Treatments } & \multicolumn{3}{|c|}{ FBG (mg/dL) } & \multicolumn{3}{c|}{ Insulin (U/L) } \\
\cline { 3 - 4 } & \multirow{2}{*}{ Day 0 } & \multicolumn{2}{|c|}{ Week 10 } & \multirow{2}{*}{ Day 0 } & \multicolumn{2}{c|}{ Week 10 } \\
\cline { 3 - 4 } \cline { 6 - 7 } & & Value & \% Change & & Value & \% Change \\
\hline NC & $77.5 \pm 2.25^{\mathrm{b}}$ & $79.8 \pm 4.92^{\mathrm{b}}$ & 2.97 & $7.6 \pm 0.36^{\mathrm{b}}$ & $7.8 \pm 0.46^{\mathrm{b}}$ & 2.63 \\
\hline MCE-400 & $80.6 \pm 2.70$ & $78.2 \pm 3.71$ & -2.98 & $7.2 \pm 0.25$ & $7.5 \pm 0.38$ & 4.17 \\
\hline STZ control & $281.5 \pm 8.47^{\mathrm{a}}$ & $272.8 \pm 8.16^{\mathrm{a}}$ & -3.09 & $3.3 \pm 0.15^{\mathrm{a}}$ & $3.1 \pm 0.18^{\mathrm{a}}$ & -6.06 \\
\hline STZ plus GLB & $269.1 \pm 8.15^{\mathrm{a}}$ & $96.7 \pm 5.81^{\mathrm{b}}$ & -64.07 & $3.4 \pm 0.17^{\mathrm{a}}$ & $5.7 \pm 0.40^{\mathrm{ab}}$ & 67.65 \\
\hline STZ plus MCE-200 & $273.6 \pm 8.17^{\mathrm{a}}$ & $149.9 \pm 6.30^{\mathrm{ab}}$ & -45.21 & $3.5 \pm 0.15^{\mathrm{a}}$ & $4.8 \pm 0.25^{\mathrm{ab}}$ & 37.14 \\
\hline STZ plus MCE-400 & $279.4 \pm 8.55^{\mathrm{a}}$ & $140.0 \pm 6.98^{\mathrm{ab}}$ & -49.89 & $3.3 \pm 0.14^{\mathrm{a}}$ & $4.9 \pm 0.28^{\mathrm{ab}}$ & 48.48 \\
\hline
\end{tabular}

Values are expressed as mean $\pm \mathrm{SE}(\mathrm{n}=6) ;{ }^{\mathrm{a}} \mathrm{p} \leq 0.05$, statistically significant in comparison with the normal control (NC) group; ${ }^{\mathrm{b}} \mathrm{p} \leq 0.05$ statistically significant in comparison with STZ control group; \%change: percentage change from the corresponding values on day 0 ;

Multiple group comparisons were performed by analysis of variance (ANOVA) followed by Dunnett's multiple comparison test at $\mathrm{p} \leq 0.05$

Effect on cardiac damage markers in serum

Levels of AST, LDH, CK, CK-MB and cTnI in the serum were assessed as markers of cardiac injury after 10 weeks of GLB and MCE treatments (Table II). In the STZ control rats, levels of AST, LDH, CK, CK$\mathrm{MB}$ and $\mathrm{cTnI}$ were significantly higher $(\mathrm{p} \leq 0.05)$, in comparison with the NC group. GLB showed minor decreases in the serum levels of these biomarkers with insignificant protection against diabetes-induced cardiac injury. Oral administration of MCE-200 and MCE-400 significantly $(\mathrm{p} \leq 0.05)$ attenuated the increased serum levels of these biomarkers in diabetic rats, as compared to STZ control animals. The best result was obtained in the STZ diabetic group that received MCE-400.

Effect of GLB and MCE on the serum levels of myocardial injury markers in STZ-diabetic rats

\begin{tabular}{|l|c|c|c|c|c|}
\hline \multicolumn{1}{|c|}{ Treatments } & $\begin{array}{c}\text { AST } \\
(\mathrm{U} / \mathrm{L})\end{array}$ & $\begin{array}{c}\text { LDH } \\
(\mathrm{U} / \mathrm{L})\end{array}$ & $\begin{array}{c}\text { CK } \\
(\mathrm{U} / \mathrm{L})\end{array}$ & $\begin{array}{c}\text { CK-MB } \\
(\mathrm{U} / \mathrm{L})\end{array}$ & $\begin{array}{c}\text { cTnI } \\
(\mathrm{ng} / \mathrm{mL})\end{array}$ \\
\hline NC & $85.8 \pm 2.48^{\mathrm{b}}$ & $165.6 \pm 10.62^{\mathrm{b}}$ & $208.6 \pm 15.25^{\mathrm{b}}$ & $14.8 \pm 0.83^{\mathrm{b}}$ & $1.3 \pm 0.05^{\mathrm{b}}$ \\
\hline MCE-400 & $82.2 \pm 3.16$ & $161.8 \pm 8.52$ & $210.4 \pm 11.50$ & $15.5 \pm 0.96$ & $1.4 \pm 0.09$ \\
\hline STZ control & $217.5 \pm 14.22^{\mathrm{a}}$ & $297.5 \pm 11.20^{\mathrm{a}}$ & $375.2 \pm 17.38^{\mathrm{a}}$ & $22.5 \pm 0.96^{\mathrm{a}}$ & $2.5 \pm 0.21^{\mathrm{a}}$ \\
\hline STZ plus GLB & $182.9 \pm 9.47^{\mathrm{a}}$ & $255.3 \pm 12.42^{\mathrm{a}}$ & $327.6 \pm 15.79^{\mathrm{a}}$ & $19.9 \pm 0.95^{\mathrm{a}}$ & $2.0 \pm 0.17^{\mathrm{a}}$ \\
\hline STZ plus MCE-200 & $125.4 \pm 9.15^{\mathrm{ab}}$ & $200.7 \pm 10.94^{\mathrm{ab}}$ & $259.3 \pm 16.83^{\mathrm{ab}}$ & $17.8 \pm 1.03^{\mathrm{ab}}$ & $1.6 \pm 0.10^{\mathrm{ab}}$ \\
\hline STZ plus MCE-400 & $98.7 \pm 6.15^{\mathrm{b}}$ & $183.7 \pm 11.83^{\mathrm{b}}$ & $217.8 \pm 14.48^{\mathrm{b}}$ & $15.9 \pm 0.94^{\mathrm{b}}$ & $1.4 \pm 0.11^{\mathrm{b}}$ \\
\hline
\end{tabular}

Values are expressed as mean $\pm \mathrm{SE}(\mathrm{n}=6) ;{ }^{\mathrm{a}} \mathrm{p} \leq 0.05$, statistically significant in comparison with the normal control (NC) group; ${ }^{\mathrm{b}} \mathrm{p} \leq 0.05$, statistically significant in comparison with STZ control group; Multiple group comparisons were performed by analysis of variance

(ANOVA) followed by Dunnett's multiple comparison test at $\mathrm{p} \leq 0.05$

Effect on cardiac and LV hypertrophy indices

In order to estimate the effect of MCE on cardiac hypertrophy, the whole cardiac muscle and the left ventricle of each animal were weighed at the end of the study. The ratio of $\mathrm{HW} / \mathrm{BW}$ and the ratio of LVW/BW were calculated as indicators of cardiac hypertrophy (Table III). Diabetic animals had cardiac hypertrophy, as indicated by the elevated ratios of
HW/BW and LVW/BW. Administration of GLB for 10 weeks failed to modify these alterations. However, rats treated with MCE had reduced cardiac hypertrophy and LV hypertrophy indexes, as compared to STZ control group $(\mathrm{p} \leq 0.05)$. It is worth remarking that medication of diabetic rats with MCE-400 reversed these parameters back to normal values.

Table III

Effect of GLB and MCE on cardiac and left ventricular hypertrophy indices of STZ-diabetic rats

\begin{tabular}{|l|c|c|c|c|c|c|c|}
\hline \multicolumn{1}{|c|}{ Treatments } & BW-0 $(\mathrm{g})$ & BW-10 $(\mathrm{g})$ & BW gain $(\%)$ & HW $(\mathrm{g})$ & HW/BW $(\mathrm{mg} / \mathrm{g})$ & LVW $(\mathrm{g})$ & LVW/BW $(\mathrm{mg} / \mathrm{g})$ \\
\hline NC & $217.1 \pm 11.5$ & $315.1 \pm 10.7$ & $45.14 \pm 2.46^{\mathrm{b}}$ & $1.12 \pm 0.05^{\mathrm{b}}$ & $3.55 \pm 0.18^{\mathrm{b}}$ & $0.374 \pm 0.02^{\mathrm{b}}$ & $1.19 \pm 0.07^{\mathrm{b}}$ \\
\hline MCE-400 & $209.1 \pm 9.6$ & $305.8 \pm 12.5$ & $46.25 \pm 2.85$ & $1.19 \pm 0.07$ & $3.89 \pm 0.16$ & $0.356 \pm 0.03$ & $1.16 \pm 0.06$ \\
\hline STZ control & $208.6 \pm 10.3$ & $240.3 \pm 10.8$ & $15.20 \pm 1.12^{\mathrm{a}}$ & $1.54 \pm 0.08^{\mathrm{a}}$ & $6.41 \pm 0.37^{\mathrm{a}}$ & $0.615 \pm 0.05^{\mathrm{a}}$ & $2.56 \pm 0.20^{\mathrm{a}}$ \\
\hline STZ plus GLB & $220.3 \pm 13.6$ & $281.8 \pm 10.1$ & $27.92 \pm 1.15^{\mathrm{ab}}$ & $1.52 \pm 0.07^{\mathrm{a}}$ & $5.39 \pm 0.29^{\mathrm{a}}$ & $0.577 \pm 0.02^{\mathrm{a}}$ & $2.05 \pm 0.14^{\mathrm{a}}$ \\
\hline STZ plus MCE-200 & $205.6 \pm 8.7$ & $273.5 \pm 9.8$ & $33.03 \pm 1.74^{\mathrm{ab}}$ & $1.30 \pm 0.06^{\mathrm{ab}}$ & $4.75 \pm 0.17^{\mathrm{b}}$ & $0.425 \pm 0.01^{\mathrm{ab}}$ & $1.55 \pm 0.06^{\mathrm{ab}}$ \\
\hline STZ plus MCE-400 & $215.4 \pm 9.9$ & $298.3 \pm 10.5$ & $38.49 \pm 1.85^{\mathrm{b}}$ & $1.22 \pm 0.06^{\mathrm{b}}$ & $4.09 \pm 0.20^{\mathrm{b}}$ & $0.368 \pm 0.03^{\mathrm{b}}$ & $1.23 \pm 0.08^{\mathrm{b}}$ \\
\hline
\end{tabular}

Values are expressed as mean $\pm \mathrm{SE}(\mathrm{n}=6)$; ${ }^{\mathrm{a}} \mathrm{p} \leq 0.05$, statistically significant in comparison with the normal control (NC) group; ${ }^{\mathrm{b}} \mathrm{p} \leq 0.05$, statistically significant in comparison with STZ control group; Multiple group comparisons were performed by analysis of variance (ANOVA) followed by Dunnett's multiple comparison test at $\mathrm{p} \leq 0.05$ 
Effect on $B P$ and $H R$

Table IV shows the effect of the treatments with GLB, MCE-200 and MCE-400 on haemodynamic parameters, including SBP, DBP and HR in rats. The induction of STZ-diabetes did not alter the diastolic blood pressure of rats but significantly increased the values of their systolic blood pressure and heart rate, more than the normal control rats (Table IV). However, the SBP and HR values in STZ-diabetic animals were remarkably reversed $(\mathrm{p} \leq 0.05)$ after GLB, MCE-200, or MCE-400 medications for 10 weeks. Administering MCE-400 to diabetic animals tends to bring back the SBP and HR to normal values.

Effect of GLB and MCE on systolic blood pressure (SBP), diastolic blood pressure (DBP) and heart rate (HR) of

Table IV
(HR) of

STZ-diabetic rats

\begin{tabular}{|l|c|c|c|}
\hline \multicolumn{1}{|c|}{ Treatments } & $\begin{array}{c}\text { SBP } \\
(\mathrm{mmHg})\end{array}$ & $\begin{array}{c}\text { DBP } \\
(\mathrm{mmHg})\end{array}$ & $\begin{array}{c}\text { HR } \\
(\mathrm{beats} / \mathrm{min})\end{array}$ \\
\hline NC & $126.8 \pm 4.15^{\mathrm{b}}$ & $85.2 \pm 3.37$ & $349.8 \pm 5.72^{\mathrm{b}}$ \\
\hline MCE-400 & $128.4 \pm 3.85$ & $88.4 \pm 3.53$ & $345.5 \pm 8.5$ \\
\hline STZ control & $154.4 \pm 4.12^{\mathrm{a}}$ & $87.5 \pm 3.11$ & $387.7 \pm 5.73^{\mathrm{a}}$ \\
\hline STZ plus GLB & $141.3 \pm 4.05^{\mathrm{ab}}$ & $86.1 \pm 3.50$ & $370.4 \pm 5.17^{\mathrm{ab}}$ \\
\hline STZ plus MCE-200 & $140.2 \pm 4.23^{\mathrm{ab}}$ & $86.7 \pm 3.72$ & $367.5 \pm 5.01^{\mathrm{ab}}$ \\
\hline STZ plus MCE-400 & $133.7 \pm 4.77^{\mathrm{b}}$ & $85.4 \pm 3.69$ & $352.6 \pm 7.17^{\mathrm{b}}$ \\
\hline
\end{tabular}

Values are expressed as mean $\pm \mathrm{SE}(\mathrm{n}=6) ;{ }^{\mathrm{a}} \mathrm{p} \leq 0.05$, statistically significant in comparison with the normal control (NC) group; ${ }^{\mathrm{b}} \mathrm{p} \leq 0.05$, statistically significant in comparison with STZ control group; Multiple group comparisons were performed by analysis of variance (ANOVA) followed by Dunnett's multiple comparison test at $\mathrm{p} \leq 0.05$

\section{Effect on serum lipid profile}

Table V lists the levels of TGs, TC, HDL-C, LDL-C and VLDL-C in the serum of normal and experimental animals. STZ control rats manifested a remarkable $(\mathrm{p} \leq 0.05)$ elevation in these parameters, with the levels of HDL-C being the exception, where there was a significant $(p<0.05)$ reduction, in comparison with the values of $\mathrm{NC}$ rats. Administration of GLB or MCE-200 to diabetic animals significantly $(p \leq 0.05)$ reversed their lipid profile imbalance, as compared to the STZ control group, but the levels remained significantly elevated, as compared to the NC animals.
Significant improvements of the lipid profile were also obtained in the serum of diabetic rats exposed to MCE-400. In this group, the diabetic rats tended towards normal values of the serum lipid profile.

To evaluate the impact of hyperlipidaemia on the heart and blood vessels and the protective effect of MCE, the atherogenic index (AI) was determined. This index showed a pronounced $(\mathrm{p} \leq 0.05)$ elevation in STZ control rats (Table V). Only MCE-400 treated rats exhibited improved atherogenic indexes as compared to STZ control rats.

Table V

Effect of GLB and MCE on the serum levels of lipid profile in STZ-diabetic rats

\begin{tabular}{|l|c|c|c|c|c|c|}
\hline \multicolumn{1}{|c|}{ Treatments } & $\begin{array}{c}\text { TG } \\
(\mathrm{mg} / \mathrm{dL})\end{array}$ & $\begin{array}{c}\text { TC } \\
(\mathrm{mg} / \mathrm{dL})\end{array}$ & $\begin{array}{c}\text { HDL-C } \\
(\mathrm{mg} / \mathrm{dL})\end{array}$ & $\begin{array}{c}\text { LDL-C } \\
(\mathrm{mg} / \mathrm{dL})\end{array}$ & $\begin{array}{c}\text { VLDL } \\
(\mathrm{mg} / \mathrm{dL})\end{array}$ & AI \\
\hline NC & $56.4 \pm 2.93^{\mathrm{b}}$ & $64.5 \pm 3.63^{\mathrm{b}}$ & $35.4 \pm 1.85 \mathrm{~b}$ & $16.7 \pm 0.93^{\mathrm{b}}$ & $11.28 \pm 0.74^{\mathrm{b}}$ & $0.451 \pm 0.04^{\mathrm{b}}$ \\
\hline MCE-400 & $52.5 \pm 2.85$ & $60.3 \pm 2.85$ & $39.7 \pm 1.49$ & $14.2 \pm 0.60$ & $10.50 \pm 0.65$ & $0.342 \pm 0.02$ \\
\hline STZ control & $130.2 \pm 4.26^{\mathrm{a}}$ & $104.7 \pm 3.26^{\mathrm{a}}$ & $18.5 \pm 0.42^{\mathrm{a}}$ & $59.8 \pm 2.95^{\mathrm{a}}$ & $26.04 \pm 0.84^{\mathrm{a}}$ & $0.823 \pm 0.06^{\mathrm{a}}$ \\
\hline STZ plus GLB & $107.6 \pm 4.30^{\mathrm{ab}}$ & $85.3 \pm 3.30^{\mathrm{ab}}$ & $22.3 \pm 0.72^{\mathrm{ab}}$ & $43.5 \pm 1.81^{\mathrm{ab}}$ & $21.52 \pm 0.72^{\mathrm{ab}}$ & $0.739 \pm 0.05^{\mathrm{a}}$ \\
\hline STZ plus MCE-200 $^{\mathrm{a}}$ & $83.7 \pm 3.24^{\mathrm{ab}}$ & $79.4 \pm 3.24^{\mathrm{ab}}$ & $25.9 \pm 0.49^{\mathrm{ab}}$ & $32.6 \pm 1.99^{\mathrm{ab}}$ & $16.74 \pm 0.50^{\mathrm{ab}}$ & $0.674 \pm 0.06^{\mathrm{a}}$ \\
\hline STZ plus MCE-400 & $66.2 \pm 3.97^{\mathrm{b}}$ & $73.5 \pm 3.77^{\mathrm{b}}$ & $31.4 \pm 0.83^{\mathrm{b}}$ & $19.5 \pm 0.94^{\mathrm{b}}$ & $13.24 \pm 0.56^{\mathrm{b}}$ & $0.573 \pm 0.04^{\mathrm{b}}$ \\
\hline
\end{tabular}

Values are expressed as mean $\pm \mathrm{SE}(\mathrm{n}=6)$; ${ }^{\mathrm{a}} \mathrm{p} \leq 0.05$, statistically significant in comparison with the normal control $(\mathrm{NC})$ group; ${ }^{\mathrm{b}} \mathrm{p} \leq 0.05$, statistically significant in comparison with STZ control group; Multiple group comparisons were performed by analysis of variance (ANOVA) followed by Dunnett's multiple comparison test at $\mathrm{p} \leq 0.05$

Effect on STZ-induced oxidative stress markers in cardiac tissues

The activities of the antioxidant enzymes SOD, GPx and CAT, along with the levels of GSH and MDA in the cardiac tissues of rats are listed in Table VI. Activities of SOD, GPx and CAT were significantly $(p \leq 0.05)$ reduced in the cardiac homogenates of the STZ control group, as compared to the NC rats. The STZ control group showed significantly $(p \leq 0.05)$ reduced levels of GSH - an endogenous antioxidant in their heart tissue, as compared to the NC group. Administration of GLB did not improve the activities of the cardiac antioxidant enzymes in diabetic rats, as compared to the STZ control group. However, MCE significantly protected against diabetes-induced reduction in the activities of cardiac SOD, GPx and CAT enzymes. Both doses of MCE resulted in significantly increased levels of SOD, GPx and CAT, and GSH in comparison with STZ control rats. Interestingly, the MCE-400 was able to successfully normalize the antioxidant markers in the cardiac tissues of diabetic rats, after 10 weeks of medication. The data in Table VI indicates that the exposure of rats to STZ resulted in severe lipid peroxidation (LPO) in cardiac tissues, as evidenced 
by the significant elevation in the cardiac content of MDA, as compared to the NC rats. Medication of diabetic rats with GLB did not change the content of MDA, as compared to STZ control rats. However, treatment with both doses of MCE resulted in a significant reduction of the cardiac contents of MDA, as compared to the STZ control group $(\mathrm{p} \leq 0.05)$.

Table VI

Effect of GLB and MCE on antioxidant enzymes, reduced glutathione and lipid peroxidation in the heart homogenate of STZ-diabetic rats

\begin{tabular}{|l|c|c|c|c|c|}
\hline \multicolumn{1}{|c|}{ Treatments } & $\begin{array}{c}\text { SOD } \\
(\text { U/mg protein })\end{array}$ & $\begin{array}{c}\text { GPx } \\
(\text { U/mg protein })\end{array}$ & $\begin{array}{c}\text { CAT } \\
(\text { U/mg protein })\end{array}$ & $\begin{array}{c}\text { GSH } \\
(\mu \text { mol/g tissue })\end{array}$ & $\begin{array}{c}\text { MDA } \\
(\text { nmol/g tissue })\end{array}$ \\
\hline NC & $63.7 \pm 2.45^{\mathrm{b}}$ & $5.6 \pm 0.37^{\mathrm{b}}$ & $17.8 \pm 0.75^{\mathrm{b}}$ & $9.5 \pm 0.86^{\mathrm{b}}$ & $1.15 \pm 0.11^{\mathrm{b}}$ \\
\hline MCE-400 & $72.2 \pm 2.46^{\mathrm{a}}$ & $8.5 \pm 0.34^{\mathrm{a}}$ & $21.7 \pm 1.15^{\mathrm{a}}$ & $11.8 \pm 0.52^{\mathrm{a}}$ & $1.06 \pm 0.07$ \\
\hline STZ control & $35.2 \pm 1.73^{\mathrm{a}}$ & $2.7 \pm 0.12^{\mathrm{a}}$ & $8.2 \pm 0.65^{\mathrm{a}}$ & $3.7 \pm 0.27^{\mathrm{a}}$ & $3.27 \pm 0.21^{\mathrm{a}}$ \\
\hline STZ plus GLB & $40.5 \pm 1.87^{\mathrm{a}}$ & $3.2 \pm 0.18^{\mathrm{a}}$ & $9.4 \pm 0.76^{\mathrm{a}}$ & $4.1 \pm 0.29^{\mathrm{a}}$ & $2.91 \pm 0.13^{\mathrm{a}}$ \\
\hline STZ plus MCE-200 & $49.2 \pm 1.62^{\mathrm{ab}}$ & $3.1 \pm 0.28^{\mathrm{ab}}$ & $11.5 \pm 0.87^{\mathrm{ab}}$ & $5.4 \pm 0.32^{\mathrm{ab}}$ & $2.17 \pm 0.15^{\mathrm{ab}}$ \\
\hline STZ plus MCE-400 & $56.7 \pm 2.36^{\mathrm{b}}$ & $4.5 \pm 0.35^{\mathrm{b}}$ & $14.5 \pm 1.58^{\mathrm{b}}$ & $7.2 \pm 0.70^{\mathrm{b}}$ & $1.55 \pm 0.15^{\mathrm{b}}$ \\
\hline
\end{tabular}

Values are expressed as mean $\pm \mathrm{SE}(\mathrm{n}=6) ;{ }^{\mathrm{a}} \mathrm{p} \leq 0.05$, statistically significant in comparison with the normal control (NC) group; ${ }^{\mathrm{b}} \mathrm{p} \leq 0.05$, statistically significant in comparison with STZ control group; Multiple group comparisons were performed by analysis of variance (ANOVA) followed by Dunnett's multiple comparison test at $p \leq 0.05$

\section{Effect on heart histopathology}

Cardiotoxicity induced by STZ was further assessed using haematoxylin and eosin-stained sections. As shown in Figure 1A, hearts from the NC and nondiabetic groups received a plant extract that demonstrated typical myocardial histology. In these groups, heart tissues showed the usual structure of myofibrils with striations, branched appearance and continuity with adjacent myofibrils. On the contrary, heart sections of diabetic rats (Figure 1B) exhibited extensive damage of the myocardial tissues. The lesions were characterized by myocardial degeneration and multiple necrotic

A

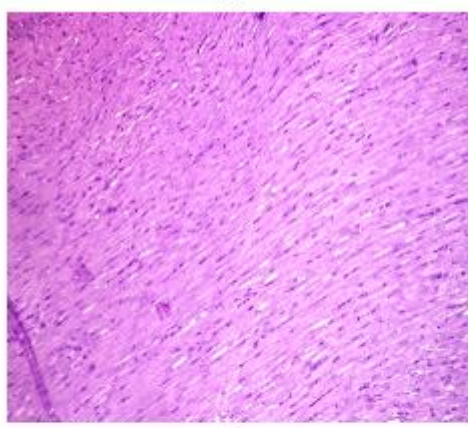

D

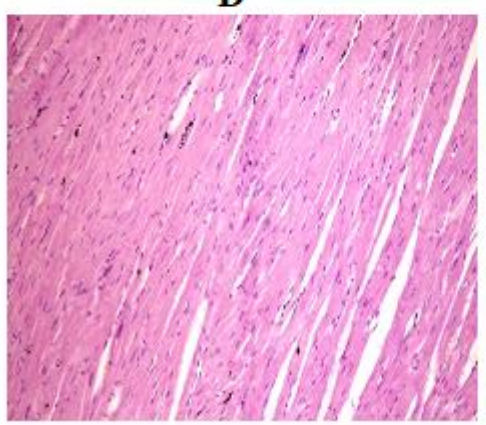

B

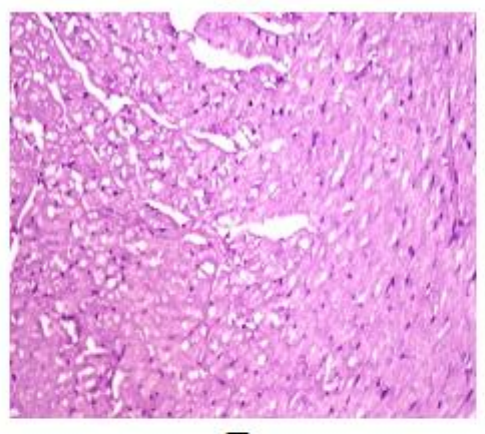

$\mathbf{E}$

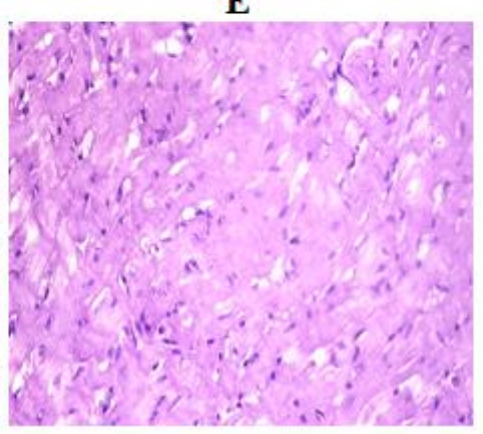

foci of myocardial fibres, with cytoplasmic vacuole formation, marked oedema and accumulation of inflammatory cells. Administration of GLB to the diabetic rats showed mild improvement in the altered histopathological pattern (Figure 1C), as compared to the STZ control rats. Despite the persistence of some necrotic foci, oedema and inflammation in the myocardial tissues of diabetic animals treated with MCE-200 (Figure 1D), the treatment with MCE-400 showed a well-preserved appearance of myocardial fibres with a slight degree of oedema (Figure 1E).

Figure 1.

Photomicrographs of rat's heart (H\&E X400), (A) Normal control group; (B) STZ-control group; (C) STZ plus GLB; (D) STZ plus MCE-200; (E) STZ plus MCE-400 
This study suggests that MCE administered at 4000 $\mathrm{mg} / \mathrm{kg}$ b.w. is not likely to produce toxic effects in rats. Consequently, it is suggested that LD50 of MCE was higher than $4000 \mathrm{mg} / \mathrm{kg}$ b.w. by weight. Generally, the lower the LD50 value, the higher the toxicity of the compound. Thus, the ethanol extract of MC flowers can be considered as non-toxic. Additionally, compounds having LD50 more than $4 \mathrm{~g} / \mathrm{kg}$ b.w. are considered safe or practically nontoxic [10]. The safe nature of MCE, as acknowledged in the acute toxicity study is well supported, following the medication of normal rats for 10 weeks. The treatment with $400 \mathrm{mg} / \mathrm{kg}$ b.w. of MCE was well tolerated by the rats, since there were no toxic signs or deaths observed during the experimental period.

Administration of MCE at $400 \mathrm{mg} / \mathrm{kg}$ b.w. for 10 weeks did not significantly affect the serum values of glucose, insulin, AST, LDH, CK, CK-MB, cTnI, TGs, TC, HDL-C and LDL-C of non-diabetic animals, as compared to the $\mathrm{NC}$ group, suggesting that the general metabolic condition of male rats was within the usual range. It did not influence SBP, DBP, HR and $\mathrm{AI}$ in the treated rats. The antioxidant enzymes and GSH in the myocardial tissues of non-diabetic animals increased following the MCE medication for 10 weeks.

DM is a complex set of carbohydrate, lipid and protein metabolism disorders, characterized by hyperglycaemia, owing to partial or absolute insulin deficiency. The principal approach to controlling DM is lowering blood glucose levels. In this investigation, STZ-control animals demonstrated high FBG and low insulin levels, which are indicative of DM. GLB or MCE (200 and $400 \mathrm{mg} / \mathrm{kg}$ b.w.) administration seems to counteract these diabetic effects. This indicates that MCE is capable of increasing the capability of insulin to reduce blood sugar, confirming its anti-diabetic effect. Notably, the useful effect on diabetes management observed for GLB and MCE occurs without an increased risk of hypoglycaemia. GLB improves hyperglycaemia, mostly by blocking the ATP-sensitive potassium channels in $\beta$-pancreatic cells, which results in depolarizing the cell membrane and opening a voltage-dependent $\mathrm{Ca}^{2+}$ channel. Accordingly, the level of intracellular $\mathrm{Ca}^{2+}$ in the $\beta$-pancreatic cells increases and results in the stimulation of insulin release, that is to say, the release of preformed insulin [11]. Various mechanisms have been mentioned in previous researches to explain the possible antidiabetic activities of MCE. These mechanisms include reducing blood glucose levels, increasing hepatic glycogen storage and suppression of sorbitol in the human erythrocytes [12]. The therapeutic activity of MCE may be owed to its protective effect on $\beta$-cells of the pancreas against diabetes-related oxidative stress [5].

$\mathrm{DM}$ is a metabolic disorder that is associated with an increased risk of cardiovascular complications. Heart tissues contain abundant levels of myocardial damage biomarkers, such as AST, LDH, CK, CK-MB and cTnI [13]. The World Health Organization suggested AST, LDH and CK as the biomarkers of cardiac injury [14]. These enzymes are strongly linked to the contractile apparatus of the myocardial tissue. The increased blood glucose level in DM enhances the generation of ROS, leading to membrane peroxidation and disruption of cardiomyocytes [15]. This can lead to leakage of myocardial damage biomarkers into the process of blood circulation. The serum levels of these markers correspond to the degree of damage to the heart tissue. In the present investigation, increased serum levels of AST, LDH, CK and CK-MB indicated STZ-induced myocardial damage. Interestingly, the treatment with MCE reduced the release of these indicators into the circulation in a dose-dependent manner, indicating protection against diabetes-inducing cardiac damage and offering cardio-protection.

Troponins are a complex of three protein subunits: troponin I (TnI), troponin $\mathrm{T}(\mathrm{TnT})$ and troponin $\mathrm{C}$. Troponin I (cTnI) and troponin $\mathrm{T}$ (cTnT) are cardiac regulatory proteins that regulate the $\mathrm{Ca}^{2+}$ mediated interaction between actin and myosin [16]. Assessment of cTnI in the blood is highly sensitive and more specific in the identification of myocardial damage [17]. In this investigation, the STZ control rats demonstrated a significant increase in the level of $\mathrm{cTnI}$ in the serum. MCE induced a marked reduction in diabetes-induced high serum levels of cTnI. This decrease in the cTnI level confirms that MCE is responsible for maintaining the normal myocardial structure. The cardioprotective effect of MCE may be due to the bioactive compounds of the plant. The major constituents of MCE, which are accountable for most of its activities, may be attributed to the high content of terpenes and flavonoids [18].

The HW/BW and LVW/BW ratios serve as indices of cardiac hypertrophy [19]. In this investigation, the STZ control animals were found to show increased HW and LVW weights and their ratios to body weight. Diabetes-induced myocardial hypertrophy was attenuated through the administration of MCE-400 treatment, as evidenced by normal HW/BW and LVW/BW ratios. These results assured that MCE provoked myocardial protection against diabetes cardiotoxicity. This phenomenon may be attributed to the capability of MCE to facilitate adequate glycaemic and hemodynamic control, in addition to its antioxidant activity.

The strong relationship between hypertension and DM has been described in several reports [20, 21]. In our study, diabetic animals demonstrated a marked elevation in the systolic blood pressure, with no changes in the diastolic blood pressure. Dyslipidaemia has been shown to contribute to endothelial damage that may manifest as elevated systemic blood pressure [22]. The Asteraceae family was reported for its ability to lower blood pressure [23]. We observed that MCE showed a significant decrease in systolic blood pressure, 
FARMACIA, 2020, Vol. 68, 2

as compared to the STZ control group, while the diastolic blood pressure remained unchanged. The decrease in BP, following the administration of the extract, may be due to the amelioration of lipid homeostasis and/or the ability of the extract to relieve hyperglycaemia in diabetic animals. In a previous study, the effect of $M$. chamomilla L. on blood pressure was evaluated in rats [24]. The total alcohol extract from the aerial parts of the plant showed blood pressure lowering effects in hypertensive rats, with ACE inhibitory activity as a mechanism of action. The blood pressure lowering effect of the plant could be attributed to its phenolic content.

A detrimental influence of DM on myocardial efficiency has been well documented in isolated heart preparation [25] and intact anesthetized animals [26]. Fein et al. [27] depicted seriously harmful effects of DM on myocardial papillary muscles of rats. In addition, Borges et al. [28] findings indicate that the myocardial disorder in DM may be caused by distinguished metabolic changes in the myocardium as a result of insulin deficiency. Furthermore, our study showed tachycardia in diabetic rats. The developed tachycardia in diabetics, in some patients, may be due to cardiac parasympathetic damage [29].

Lipid abnormalities represent a considerable risk factor for cardiovascular disorders in diabetic patients [30]. In addition, one study showed widespread lipid abnormalities in patients with diabetes, such as hypertriglyceridaemia, hypercholesterolaemia and elevated LDL-C, which are well known risk factors for cardiovascular disorders [31]. The increased level of lipids in the blood of diabetics is largely due to an elevation in the mobilization of free fatty acids from peripheral fat depots through lipolysis [32]. TGs are neutral fats, and a major energy reserve for the body, stored as adipose tissue. In our investigation, TGs increased significantly in STZ control animals. Some previous reports showed that insulin regulates the enzymatic activity of lipoprotein lipase (LPL). It interacts with TGs-rich lipoprotein in endothelial cells, where it hydrolyses TGs into FFAs [33]. In the diabetic state, insulin insufficiency reduces the LPL activity, thus leading to hypertriglyceridaemia [34]. The high concentration of TGs in the serum of STZ-diabetic rats was restored following the MCE medication. This could be due to the improved insulin secretion, which in turn increases LPL activity. Hypercholesterolaemia is one of the most noted lipid disorders in DM. TC levels were elevated due to increased cholesterol biosynthesis in DM [35]. Our STZ model exhibited the main features of diabetic dyslipidaemia, including low serum HDL-C levels. HDL-C plays an important role in antagonizing atherosclerosis by transferring cholesterol from peripheral tissues to the liver for excretion. The decrease in the level of HDL-C in STZ control animals may be because of the acceleration of apoA-I clearance from the blood, owing to increased cholesterol [36]. The relation between an increased risk of myocardial disorders and reduced levels of HDL-C is well documented, independent of TG levels and other risk factors [37].

LDL-C that is formed from the VLDL-C is strongly and positively related to atherosclerotic complications. Elevated levels of LDL-C are injurious in cases of $\mathrm{DM}$, as its oxidation leads to plaque formation in the walls of the blood vessels, leading to the incidence of atherosclerosis [38]. In the present study, LDL-C levels were increased in the STZ-control rats. VLDL$\mathrm{C}$ is involved in the transport of cholesterol from the liver to peripheral tissues. VLDL-C levels were also increased in the present study in the STZ control rats, denoting an increased production of LDL-C. This could be regarded as a possible cause in the development of atherogenesis. The AI has been proposed as a marker of serum atherogenicity. The higher the atherogenic index, the greater the risk of myocardial disorders [39]. In our study, MCE-400 markedly improved the levels of TGs, TC and LDL-C that might be attributed to its antioxidant effect and its ability to control diabetes, suggesting a decreased risk of cardiovascular diseases. Interestingly the MCE-400 was better at regulating the serum lipid profile and reducing AI in diabetic rats than the GLB therapy, indicating its potent antihyperlipidaemic, antiatherogaenic and cardioprotective effects. Reductions in serum lipids, particularly of the TGs and LDL-C, to normal levels are considered beneficial for the long-term prognosis of diabetic patients [40]. Since MCE-400 produced further improvement in the lipid profile than that was produced by the GLB, it is suggested that the MCE-400 may be acting through some mechanism different from that of the GLB on lipid metabolic pathways. Weidner et al. [41] proposed that ethanolic extract of chamomile flowers ameliorates lipid profile levels by modulating the PPAR- $\gamma$ gene expression.

The role of oxidative stress in the development of diabetes complications is well-known [42]. In DM, oxidative stress emerges as a result of different mechanisms, including high ROS generation from glucose auto-oxidation and glycation of antioxidant enzymes. Previous literature reported that oxidative stress represents the unifying factor in the development of the cardiovascular complications in diabetes [43]. Within the body cells, enzymatic (SOD, CAT and GPx) and non-enzymatic (GSH) antioxidants represent the two major antioxidant defence systems. Oxidative stress manifests when the generation of ROS by the cells overrides the capability of the cellular antioxidant defence systems. In this study, the activities of SOD, GPx and CAT were reduced in the myocardial tissues of the STZ control rats, confirming that their antioxidant defence systems were compromised. Suppression of the activities of these enzymes in STZ-control rats may be due to the increased production of ROS. Our results demonstrated that MCE (200 and $400 \mathrm{mg} / \mathrm{kg}$ ) 
attenuated the diabetes-induced alterations on the cardiac antioxidant enzyme activities, as compared to untreated diabetic rats that were dosed dependently. MCE-400 repaired the reduced levels of the myocardial antioxidant enzymes to near normal rates. Amelioration in the activities of SOD, CAT and GPx enzymes provides proof that MCE protects against oxidative stress and reduces diabetes-induced myocardial damage in rats. GSH is depleted in case of oxidative stress induced by diabetes and converted to GSH-disulphide, leading to LPO and cellular damage. Accordingly, GSH is assumed to be a considerable indicator for the estimation of oxidative stress [44]. In this investigation, the decrease in GSH in heart tissue of the STZ control rats indicated an increase in oxidative stress. Depletion of cellular GSH leaves the cells vulnerable to oxidative stress [45]. On the other hand, administration of MCE-200 and MCE-400 to diabetic rats replenished the level of GSH in their heart tissues, as compared to the STZ control group. As a result, it seems that the protective effect of MCE on diabetes-induced myocardial damage is induced, at least in part, through maintaining GSH.

The increases in the myocardial content of MDA and LPO have been implicated in the pathogenesis of diabetic cardiovascular complications [46]. In the present study, the STZ injection resulted in a marked elevation in cardiac MDA content. The observed high levels of cardiac MDA in diabetic rats reflected LPO, a consequence of oxidative stress. The high myocardial MDA content suggests the failure of the cellular antioxidant system to protect against the generation of ROS. This result reinforces a previous report that showed elevated myocardial LPO, accompanied by impairment of the antioxidant situation in the diabetic animals [47]. The present investigation demonstrated that MCE treatment significantly attenuated diabetesinduced LPO in the myocardial homogenates by decreasing their MDA content. This result further confirmed the antioxidant activity of MCE that could be related to its phytoconstituents.

The data obtained following the histological examination of the myocardium supported the biochemical results. It disclosed that the myocardium of the STZ control group showed various degrees of damages that might be due to the generation of ROS by diabetes and subsequent LPO. Administration of MCE-200 and MCE-400 showed marked myocardial protection in a dose-dependent pattern, which confirmed the biochemical results.

\section{Conclusions}

In conclusion, the administration of MCE showed cardioprotective effects against the damage induced by diabetes in rats. The cardioprotective activity might arise because of the reduction of oxidative stress, lipid peroxidation and blood glucose levels due to the phytochemical constituents present in the plant. Notably, the beneficial effect on glycaemic control, observed for MCE-400, occurs without an increased risk of hypoglycaemia, thus suggesting its beneficial effect in the treatment of DM associated with hyperlipidaemia and related cardiovascular complications. Further studies are required to fully characterize the active compounds in MCE, which are responsible for these effects.

\section{Acknowledgement}

The authors are thankful to the Deanship of Scientific Research (DSR), Prince Sattam bin Abdulaziz University, Al-Kharj, Saudi Arabia, for providing the required funds to carry out this study, under research grants number 6600/03/2016.

\section{Conflict of interest}

The authors declare no conflict of interest.

\section{References}

1. Leon B, Maddox T, Diabetes and cardiovascular disease: Epidemiology, biological mechanisms, treatment recommendations and future research. World $J$ Diabetes, 2015; 6(13): 1246-1258.

2. Melendez-Ramirez LY, Richards RJ, Cefalu WT, Complications of type 1 diabetes. Endocrinol Metab Clin., 2010; 39(3): 625-640.

3. Cui TH, Li YY, Treatment of type 2 diabetes mellitus oral Chinese patent medicine literature metrology analysis. Zhongguo Zhong Yao Za Zhi, 2012; 37: 2649-2652 (available in Chinese).

4. Sharafzadeh S, Alizadeh O, German and Roman Chamomile. J Applied Pharm Sci., 2011; 1(10): 1-5.

5. Cemek M, Kaga S, Simsek N, Büyükokuroğlu ME, Konuk M, Antihyperglycemic and antooxidative potential of Matricaria chamomilla L. in streptozotocininduced diabetic rats. J Nat Med., 2008; 62: 284-293.

6. Hadaruga NG, Hadaruga DI, Tatu C, Gruia A, Costescu C, Lupea AX, Multivariate analysis (PCA) in Compositae biocompounds class. J Agroalimentary Proc Technol., 2009; 15: 201-210.

7. OECD, Acute oral toxicity-acute toxic class method, OECD Guideline for Testing of Chemicals, France, 2001; 423.

8. Kayamori F, Igarashi K, Effects of dietary nasunin on the serum cholesterol level in rats. Biosci Biotechnol Biochem., 1994; 58: 570-571.

9. Jain SK, Levine SN, Deutt J, Hollier B, Elevated lipid peroxidation levels in red blood cells of streptozotocin-treated diabetic rats. Metabolism, 1990; 39: 971-975.

10. Kennedy G, Ferenz R, Burgess B, Estimation of acute oral toxicity in rats by determination of the approximate lethal dose rather than the LD50. J App Toxicol., 1986; 6(3): 145-148.

11. Serrano-Mart'in X, Payares G, Mendoza-Le A, Glibenclamide, a blocker of $\mathrm{K}^{+}$ATP channels, shows antileishmanial activity in experimental murine cutaneous leishmaniasis. Antimicrob Agents Chemother., 2006; 50(12): 4214-4216. 
FARMACIA, 2020, Vol. 68, 2

12. Kato A, Minoshima Y, Yamamoto J, Adachi I, Watson AA, Nash RJ, Protective effects of dietary chamomile tea on diabetic complications. J Agric Food Chem., 2008; 56: 8206-8211.

13. Badole S, Chaudhari S, Jangam G, Kandhare AD, Bodhankar SL, Cardioprotective activity of Pongamia pinnata in streptozotocin-nicotinamide induced diabetic rats. BioMed Research International, 2015; 2015: 1-8.

14. Mythili S, Malathi N, Diagnostic markers of acute myocardial infarction. Biomed Rep., 2015; 3: 743-748.

15. Kohnert K, Freyse E, Salzsieder E, Glycaemic variability and pancreatic $\beta$-cell dysfunction. Curr. Diabetes Rev., 2012; 8: 345-354.

16. Wens S. Schaaf G, Michels M, Kruijshaar ME, van Gestel TJ, In't Groen S, Pijnenburg J, Dekkers DH, Demmers JA, Verdijk LB, Brusse E, van Schaik RH, van der Ploeg AT, van Doorn PA, Pijnappel WW, Elevated plasma cardiac troponin $\mathrm{T}$ levels caused by skeletal muscle damage in pompe disease. Circ Genom Precis Med., 2016; 9: 6-13.

17. Collinson P, Boa F, Gaze D, Measurement of cardiac troponins. Ann Clin Biochem., 2001; 38: 423-429.

18. Srivastava J, Gupta S, Antiproliferative and apoptotic effects of chamomile extract in various human cancer cells. J. Agricultural Food Chem., 2007; 55: 94709478.

19. Ahmed N, Advanced glycation endproducts - role in pathology of diabetic complications. Diabetes Res Clin Pract., 2005; 67: 3-21.

20. Levin G, Kestenbaum B, Chen YDI, Jacobs DR Jr, Psaty BM, Rotter JI, Siscovick DS, de Boer IH, Glucose, insulin, and incident hypertension in the multi-ethnic study of atherosclerosis. Am J Epidemiol., 2010; 172: 1144-1154.

21. Lee SW, Kim HC, Lee JM, Yun YM, Lee JY, Suh I, Association between changes in systolic blood pressure and incident diabetes in a community-based cohort study in Korea. Hypertension Res., 2017; 40: 710-716.

22. Dalal J, Padmanabhan T, Jain P, Patil S, Vasnawala H, Gulati A, LIPITENSION: Interplay between dyslipidemia and hypertension. Indian J Endocrinol Metab., 2012; 16(2): 240-245.

23. Chethan J, Pradeep Kumar PM, Prakash HS, Antidiabetic and antihypertensive potential of selected Asteraceae plant species. Am J Advanced Drug Delivery, 2014; 2(3): 355-363.

24. Awaad AA, El-Meligy RM, Zain GM, Safhi AA, Al Qurain NA, Almoqren SS, Zain YM, Sesh Adri VD, Al-Saikhan FI, Experimental and clinical antihypertensive activity of Matricaria chamomilla extracts and their angiotensin-1 converting enzyme inhibitory activity. Phytotherapy Res., 2018; 32: 1564-1573.

25. Yoon YS, Uchida S, Masuo O, Cejna M, Park JS, Gwon HC, Kirchmair R, Bahlman F, Walter D, Curry C, Hanley A, Isner JM, Losordo DW, Progressive attenuation of myocardial vascular endothelial growth factor expression is a seminal event in diabetic cardiomyopathy: restoration of microvascular homeostasis and recovery of cardiac function in diabetic cardiomyopathy after replenishment of local vascular endothelial growth factor. Circulation, 2005; 111(16): 2073-2085.
26. Broderick TL, Kopp SJ, Daar JT, Romano FD, Paulson DJ, Relation of glycosylated hemoglobin to in vivo cardiac function in response to dobutamine in spontaneously diabetic BB Wor rats. Can J Physiol Pharmacol., 1994; 72: 722-737.

27. Fein FS, Kornstein LB, Strobeck JE, Capasso JM, Sonnenblick EH, Altered myocardial mechanics in diabetic rats. Circ Res., 1980; 47: 922-933.

28. Borges G, de Oliveira M, Salgado H, Myocardial performance in conscious streptozotocin diabetic rats. Cardiovascular Diabetol., 2006; 5: 1-8.

29. Ewing D, Campbell I, Clarke B, Heart rate changes in diabetes mellitus. Lancet, 1981; 1(8213): 183-186.

30. Shirali S, Bathaie S, Nakhjavani M, Effect of crocin on the insulin resistance and lipid profile of streptozotocin-induced diabetic rats. Phytother Res., 2013; 27: 1042-1047.

31. Ozder A, Lipid profile abnormalities seen in T2DM patients in primary healthcare in Turkey: a crosssectional study. Lipids Health Dis., 2014; 13: 1-6.

32. Bopanna KN, Kannan J, Sushma G, Balaraman R, Rathod SP, Antidiabetic and antihyperlipidemic effect of neem seed, kernal powder on alloxan diabetic rabbits. Indian J Pharm., 1997; 9: 162-167.

33. Taskinen MR, Lipoprotein lipase in diabetes. Diabetes Metab Rev., 1987; 3: 551-570.

34. Pushparaj P, Low H, Manikandan J, Tan BK, Tan $\mathrm{CH}$, Anti-diabetic effects of Cichorium intybus in streptozotocin-induced diabetic rats. J Ethnopharmacol., 2007; 111(2): 430-434.

35. Kim HY, Jeong DM, Jung HJ, Jung YJ, Yokozawa T, Choi JS, Hypolipidemic effects of sophora flavescens and its constituents in poloxamer407-induced hyperlipidemic and cholesterol-fed rats. Biol Pharm Bull., 2008; 31: 73-78.

36. Mustad VA, Etherton TD, Cooper AD, Mastro AM, Pearson TA, Jonnalagadda SS, Kris-Etherton PM, Reducing saturated fat intake is associated with increased levels of LDL receptors on mononuclear cells in healthy men and women. J Lipid Res., 1997; 38(3): 459-468.

37. Bitzur R, Cohen H, Kamari Y, Shaish A, Harats D, Triglycerides and HDL Cholesterol: Stars or second leads in diabetes?. Diabetes Care, 2009; 32(2): 373-377.

38. Bonomini F, Tengattini S, Fabiano A, Bianchi R, Rezzani R, Atherosclerosis and oxidative stress. Histol Histopathol., 2008; 23: 381-390.

39. Subramaniam S, Subramaniam R, Rajapandian S, Uthrapathi S, Gnanamanickam VR, Dubey GP, Anti-atherogenic activity of ethanolic fraction of Terminalia arjuna bark on hypercholesterolemic rabbits. Evid Based Complement Alternat Med., 2011; 2011: 1-8.

40. Chattopadhyay R, Bandyopadhyay M, Effect of Azadirachta indica leaf extract on serum lipid profile changes in normal and streptozotocin induced diabetic rats. Afr J Biomed Res., 2005; 8: 101-104.

41. Weidner C, Wowro SJ, Rousseau M, Freiwald A, Kodelja V, Abdel-Aziz H, Kelber O, Sauer S, Antidiabetic effects of chamomile flowers extract in obese mice through transcriptional stimulation of nutrient sensors of the peroxisome proliferator- 
activated receptor (PPAR) family. PLoS ONE, 2013; 8(11): 1-16.

42. Matough F, Budin S, Hamid Z, Alwahaibi N, Mohamed $\mathrm{J}$, The Role of Oxidative Stress and Antioxidants in Diabetic Complications. Sultan Qaboos Univ Med J., 2012; 12(1): 5-18.

43. Dokken B, The Pathophysiology of cardiovascular disease and diabetes: Beyond blood pressure and lipids. Diabetes Spectrum, 2008; 21(3): 160-165.

44. Recknagel R, Glonde E, Dolak J, Waller RL, Mechanism of carbon tetrachloride toxicity. Pharmacol Ther., 1989; 43: 139-154.

45. Mahmoud AM, Dera HAS, $18 \beta$-Glycyrrhetinic acid exerts protective effects against cyclophosphamide- induced hepatotoxicity: potential role of PPAR $\gamma$ and Nrf2 upregulation. Genes \& Nutrition, 2015; 10(6): 1-13.

46. Radhiga T, Rajamanickam C, Sundaresan A, Ezhumalai M, Pugalendi KV, Effect of ursolic acid treatment on apoptosis and DNA damage in isoproterenolinduced myocardial infarction. Biochimie, 2012; 94: 1135-1142.

47. El-Agamy D, Abo-Haded H, Elkablawy M, Cardioprotective effects of sitagliptin against doxorubicininduced cardiotoxicity in rats. Exp Biol Med (Maywood), 2016; 241(14): 1577-1587. 